\title{
Efficacy of an immunotoxin to folate receptor beta in the intra-articular treatment of antigen- induced arthritis
}

Taku Nagai', Akira Kyo ${ }^{1}$, Kazuhisa Hasui', Sonshin Takao² and Takami Matsuyama*

\begin{abstract}
Introduction: We previously demonstrated that synovial sublining macrophages express folate receptor beta (FRß). The aim of this study was to evaluate the efficacy of intra-articular administration of a recombinant immunotoxin to FR $\beta$ for treating rat antigen-induced arthritis.

Methods: A monoclonal antibody (mAb) to rat FR $\beta$ was produced by immunizing mice with B300-19 cells (murine pre-B cells) transfected with the rat FR $\beta$ gene. Recombinant immunotoxin was prepared by conjugating the Fv portion of the anti-rat FR $\beta$ mAb heavy chain with a truncated Pseudomonas exotoxin $A$ and the Fv portion of the anti-rat FR $\beta$ mAb light chain. Antigen-induced arthritis was induced through intra-articular injection of methylated bovine serum albumin (mBSA) after two subcutaneous injections of mBSA and complete Freund's adjuvant. Immunotoxin was intra-articularly injected into the arthritis joint every other day for seven days after arthritis onset. Joint swelling was measured and histological scores of inflammation, synovial thickness, cartilage, and bone destruction were determined. Immunohistochemistry was performed to detect osteoclast and osteoclast precursor FRß-expressing macrophages and cathepsin K-positive cells on day 21.

Results: Intra-articular administration of the immunotoxin attenuated joint swelling (61\% suppression; $P<0.01$ compared to the control on day 21) and improved histological findings, particularly cartilage and bone destruction (scores of rats treated with control versus the immunotoxin: 2.2 versus $0.5 ; P<0.01$ ), by reducing the number of FR $\beta$-expressing macrophages and cathepsin K-positive cells.
\end{abstract}

Conclusions: Intra-articular administration of an immunotoxin to FRß is effective for improving rat antigen-induced arthritis.

\section{Introduction}

Rheumatoid arthritis (RA) is a chronic, systemic inflammatory disease characterized by synovial hyperplasia and excessive mononuclear cell infiltration in the synovium leading to cartilage and bone tissue degradation. Macrophages are the primary cell type involved in RA synovitis pathogenesis by producing TNF- $\alpha$, a primary activator of macrophages; differentiation of macrophages to osteoclasts results in bone destruction $[1,2]$. Clinical disease activity in RA is strongly correlated with the number of macrophages in synovial tissues [3,4], and anti-TNF biological agents are thought to target synovial sublining

\footnotetext{
* Correspondence: matuyama@m.kufm.kagoshima-u.ac.jp 'Department of Immunology, Graduate school of Medical and Dental Sciences, Kagoshima University, Kagoshima 890-8544, Japan Full list of author information is available at the end of the article
}

macrophages [5]. Thus, selective counteraction of synovial macrophage activation remains an attractive approach for diminishing local and systemic inflammation as well as for preventing irreversible joint damage.

We previously reported that synovial sublining macrophages express folate receptor beta (FR $\beta$ ) as a receptor for oxidized folate [6,7]. Interestingly, these FR $\beta$-expressing macrophages predominantly expressed M1 macrophage markers [8]. Because FR $\beta$ expression is limited in normal tissues, we hypothesized that removing FR $\beta$-expressing macrophages may be useful for treating RA and minimize adverse side effects. We previously demonstrated that the activity of RA synovium engrafted in severe combined immunodeficiency (SCID) mice was reduced following administration of an immunotoxin to FR $\beta$ around the synovium [9]. Furthermore, an immunotoxin to FR $\beta$

\section{() Biomed Central}

(c) 2012 Nagai et al.; licensee BioMed Central Ltd. This is an open access article distributed under the terms of the Creative Commons Attribution License (http://creativecommons.org/licenses/by/2.0), which permits unrestricted use, distribution, and reproduction in any medium, provided the original work is properly cited. 
prevented osteoclast formation in RA synovial macrophage cultures. In agreement with our previous study, several studies showed that RA synovial FR $\beta$-expressing macrophages may be potential targets for treating RA, utilizing the folate receptor (FR) as the drug delivery system [10,11].

Some RA patients develop monoarthritis and oligoarthritis during very early stages. Additionally, despite a good response of other joints to systemic administration of anti-TNF biologics in combination with diseasemodifying anti-rheumatic drugs, many patients continue to experience persistent symptoms in a single or a few joint(s) [12]. Intra-articular drug administration, radiation, or surgical synovectomy can be very useful for treating disease flare-ups, synovitis, and pain when a small number of joints are affected or in patients with joints that do not respond to systemic medications [13-16]. Indeed, intra-articularly administered corticosteroids, which are commonly used for treating RA with monoarthritis and oligoarthritis, show superior effectiveness and tolerance compared with systemic corticosteroid use. However, the effect of corticosteroids is not permanent. Furthermore, some arthritic joints are refractory to intraarticular corticosteroid injection, and additional drugs are not routinely available. A number of studies evaluating intra-articular anti-TNF injections have shown variable efficacies of this treatment [17]. Therefore, intraarticular administration of drugs with different mechanisms of action may be necessary for use as local RA therapy.

In this study, we evaluated the efficacy of intra-articular administration of a recombinant immunotoxin to FR $\beta$ for treating rat antigen-induced arthritis (AIA).

\section{Materials and methods}

Production of anti-rat FR $\beta$ monoclonal antibody (mAb)

Rat FR $\beta$ cDNA was prepared from a product derived from Lewis rat liver using (RT-PCR). Primer sequences used were 5'-tctagaaagacatggcctggaaacag-3' (forward) and 5'cccaacatggatcaggaact-3' (reverse). B300-19 (murine pre-B) cells transfected with the rat FR $\beta$ gene were prepared as previously described $[9,18]$. Balb/c mice were immunized using rat FR $\beta$ gene-transfected B300-19 cells. Lymphocytes from iliac lymph nodes and spleen lymphocytes were fused with NS-1 myeloma cells. Hybridomas were screened for their reactivity with rat FR $\beta$ gene-transfected B300-19 cells. One anti-rat FR $\beta$ mAb (4A67, immunoglobulin $\mathrm{M}(\operatorname{IgM})$ ) was selected for further evaluation. All animal studies were performed in accordance with the Ethical Guidelines for Animal Experiments of Kagoshima University (approval number: MD09074 \& MD10099).

\section{Production of a recombinant immunotoxin to rat FR $\beta$}

Mouse Ig 4A67 cDNA was obtained using RT-PCR with primers from the Ig-prime kit (Novagen, Madison, WI,
USA). Sequences were deposited in GenBank (accession number JN588994 for $\operatorname{IgV}_{\mathrm{H}}$, JN588993 for IgV $\mathrm{L}_{\mathrm{L}}$ ). Recombinant variable region fragment antibody $(\mathrm{Fv})$ constructs were produced as previously described $[9,18]$. Briefly, cysteine residues were introduced into the variable regions of the Ig heavy chain $\left(\operatorname{IgV}_{\mathrm{H}}\right)$ gene (Gly40Cys) and the light chain $\left(\operatorname{IgV}_{\mathrm{L}}\right)$ gene (Gly105Cys) using PCR and the Quick Change Site-Directed Mutagenesis kit (Stratagene, La Jolla, CA, USA). To generate plasmid constructs of these mutated genes, PCR was performed using the following primers: for the $\operatorname{IgV}_{\mathrm{H}}$ gene, $5^{\prime}$-CATATGcagatccagttggtgcagtctgga-3' (upstream) and 5'-tccggAAGCTT ttgaggagacggtgactgaggttcc-3' (downstream); for the Ig $\mathrm{V}_{\mathrm{L}}$ gene, 5'-taagaaggagatataCATATGcaaattgttctcacccagtct-3' (upstream) and 5' -gctttgttagcagccGAATTCctatttatttccaactttgtcccacagccgaacgt-3' (downstream). These primers introduced restriction enzyme sites (underlined) for cloning of the $\operatorname{IgV}_{\mathrm{H}}$ gene into the NdeI-HindIII site and the $\mathrm{IgV}_{\mathrm{L}}$ gene into the $N$ deI-EcoRI site in the pUli7 expression vector. The $\operatorname{IgV}_{\mathrm{H}}$ gene was ligated with a truncated Pseudomonas exotoxin A (PE38) gene and $\operatorname{IgV}_{\mathrm{L}}$ gene and the resultant plasmid was expressed in Escherichia coli BL21 cells. Recombinant immunotoxin (dsFv anti-FR $\beta$ PE38), which consists of the Fv portion of the anti-rat FR $\beta$ mAb heavy chain with PE38 $\left(\mathrm{V}_{\mathrm{H}^{-}}\right.$PE38) and the Fv portion of the anti-rat FR $\beta$ mAb light chain, was prepared as previously described $[9,18]$. Briefly, inclusion bodies from bacteria transfected with expression plasmids encoding the Ig $\mathrm{V}_{\mathrm{H}}$-PE38 and $\mathrm{IgV}_{\mathrm{L}}$ genes were solubilized separately and then combined. Properly folded dsFv anti-FR $\beta$-PE38 was purified using HiTrap Q (Amersham Pharmacia, Piscataway, NJ, USA) and Poros HQ (Applied Biosystems, Tokyo, Japan) anion-exchange chromatography and using TSK 3000 SW (Tosoh, Tokyo, Japan) size-exclusion chromatography. To prepare monomeric $\mathrm{IgV}_{\mathrm{H}}$-PE38 (cysteine residue modification) protein, refolded $\mathrm{IgV}_{\mathrm{H}}$-PE38 protein was reduced using $1 \mathrm{mM}$ dithiothreitol, alkylated using $10 \mathrm{mM}$ iodoacetamide, and purified as described above. Endotoxin concentrations of recombinant proteins were measured using the Limulus amebocyte lysate assay (Associates of Cape Cod, Falmouth, MA), USA. Concentrations were less than five endotoxin units per mg.

\section{Flow cytometric analysis}

Female Lewis rat (six to nine weeks old) macrophages were harvested using peritoneal lavage. Peritoneal exudate macrophages were collected on day 4 after intraperitoneal injection with $10 \mathrm{~mL}$ of $3 \%$ thioglycollate (TGC). Macrophages were collected using lavage and cultured in $10-\mathrm{cm}$ tissue culture plates in Iscove's Modified Dulbecco's Media (IMDM) containing 10\% FCS. After removing non-adherent cells, macrophages were resuspended in IMDM media. Flow cytometric analysis was performed as 
previously described [7]. Briefly, the cells were reacted with anti-FR $\beta$ or isotype-matched control mAbs, followed by allophycocyanin-conjugated goat (Fab' $)_{2}$ antimouse IgM (R\&D Systems, Minneapolis, MN, USA) and phycoerythrin-conjugated murine anti-rat CD11 b/c (OX42; BioLegend, San Diego, CA, USA). Stained cells were analyzed using a FACSAria flow cytometer (Becton Dickinson, Franklin Lakes, NJ, USA).

\section{Detection of dead cells}

TGC-injected macrophages, B300-19 cells, and rat FR $\beta$ gene-transfected B300-19 cells were incubated in the presence of $\mathrm{V}_{\mathrm{H}}$-PE38 or dsFv anti- FR $\beta$-PE38. Dead cells (sub $G_{0} / G_{1}$ cells) were detected using propidium iodide staining and flow cytometric analysis as previously described $[9,18]$. Briefly, cells were stained with propidium iodide $(50 \mu \mathrm{g} / \mathrm{mL})$ in $0.1 \%$ sodium citrate plus $0.1 \%$ Triton X-100 for 20 minutes at $4{ }^{\circ} \mathrm{C}$. Dead cells were detected using flow cytometry.

\section{Measurement of nitric oxide (NO) produced by peritoneal macrophages}

TGC-elicited peritoneal macrophages $\left(2 \times 10^{5}\right)$ were placed in 24-well plates in the presence of either $\mathrm{V}_{\mathrm{H}}$-PE38 or $\mathrm{dsFv}$ anti-FR $\beta$-PE38 and further incubated for 24 hours at $37^{\circ} \mathrm{C}$ in $5 \% \mathrm{CO}_{2}$. The medium was exchanged and cells were stimulated using $100 \mathrm{U} / \mathrm{mL}$ of IFN- $\gamma$ (Peprotec, London, UK) and $100 \mathrm{ng} / \mathrm{mL}$ of Lipopolysaccharide (LPS ) (Sigma-Aldrich, Tokyo, Japan) for an additional 24 hours. NO in the culture supernatants was measured in duplicate using the Griess reaction.

\section{Induction of AIA}

All experimental rats were immunized using two subcutaneous injections (day -21 and day -14) of $0.5 \mathrm{mg}$ methylated BSA (mBSA) dissolved in $0.05 \mathrm{~mL}$ of saline and emulsified in an equal volume of complete Freund's adjuvant $[19,20]$. Knee monoarticular arthritis was induced on day 14 after the second immunization (day 0 of AIA). The left knee joint was challenged using intraarticular injection of $0.05 \mathrm{~mL}$ of saline with $0.5 \mathrm{mg}$ of $\mathrm{mBSA}$, while the right knee joint received $0.05 \mathrm{~mL}$ of saline. Arthritis development was monitored at regular intervals by measuring knee diameters using a caliper.

\section{Treatment with an immunotoxin to rat FR $\beta$}

On day 1 of AIA, rats were randomly assigned to one of four groups and intra-articularly injected with $0.05 \mathrm{~mL}$ of either $\mathrm{V}_{\mathrm{H}}$-PE38 $(50 \mu \mathrm{g})$ or dsFv anti-FR $\beta$-PE38 $(2 \mu \mathrm{g}$, $10 \mu \mathrm{g}$, or $50 \mu \mathrm{g}$ ) every other day until day 7 . In all cases, the right knee joint remained untreated. To assess the effect of these treatments, joint swelling was expressed as the difference in diameters between the right and left knees.

\section{Conventional histology and immunohistochemistry}

Rat normal tissues were prepared as cryostat sections and fixed in cold acetone. Untreated knee joints of rats were removed on days $2,5,7,14$, and 21 after AIA induction to examine FR $\beta$-expressing macrophages. Treated knee joints of rats were removed on day 21 after AIA induction. Knee joints were fixed in cold acetone, decalcified in $0.5 \mathrm{M}$ ethylenediaminetetraacetic acid (EDTA), immersed in 20\% sucrose-PBS, and embedded in 50\% optimal cutting temperature (OCT) compound. Cryostat sections $(7 \mu \mathrm{m})$ were prepared using adhesive film (FINETEC and Leica Microsystems, Tokyo, Japan) [21]. To evaluate histological arthritis scores, the sections were stained using $\mathrm{H} \& \mathrm{E}$. All slides were evaluated by an independent observer who was blinded to the design and details of the study. Sections were graded as previously described by Williams et al. [20] based on the following three parameters: degree of cartilage destruction and bone erosions (0 to 3 ), severity of synovial infiltration and inflammatory exudates (0 to 3 ), and degree of synovial membrane thickening (0 to 2 ).

Immunohistochemistry was performed as previously described $[9,18]$. Briefly, 7- $\mu \mathrm{m}$ tissue sections were treated using $0.6 \% \mathrm{H}_{2} \mathrm{O}_{2}$ for 10 minutes to quench endogenous peroxidase. Sections were blocked using blocking solution (Protein Block Serum-Free; DAKO, Tokyo, Japan). To detect CD68 and FR $\beta$ in rat normal tissues in Table 1, sections were reacted with a mixture of mouse $\mathrm{IgG}_{1}$ and $\operatorname{IgM} \mathrm{mAbs}$ as an isotype-matched control; mouse anti-rat CD68 mAb (IgG 1 ) (AbD Serotec, Oxford, UK); mouse anti-rat FR $\beta$ mAb (IgM) and followed by anti-mouse MAX-PO secondary Ab (Nichirei Co. LTD., Tokyo, Japan). To detect E-cadherin, sections were reacted with biotinylated goat polyclonal $\mathrm{Ab}$ as an isotype-matched control; biotinylated goat anti-mouse (cross-reactive to rat) E-cadherin Ab (R\&D Systems) and followed by streptovidin-peroxidase (Invitrogen, Tokyo, Japan). To detect FR $\beta$ in arthritis joints in time course, sections were reacted with mouse IgM mAb as an isotype-matched control; mouse anti-rat FR $\beta$ mAb (IgM) and followed by anti-mouse MAX-PO secondary Ab. To detect CD68, FR $\beta$ and cathepsin $\mathrm{K}$ in arthritic joints, sections were reacted with a mixture of mouse $\operatorname{IgG}_{1}$ and IgM mAbs, and rabbit IgG as an isotype-macthed control; mouse anti-rat CD68 mAb; mouse anti-rat FR $\beta$ mAb; rabbit anti-cathepsin K Ab (Biovision, San Franscisco, CA, USA) and followed by anti-mouse MAX-PO secondary $\mathrm{Ab}$.

These sections were visualized using a DAB staining kit (DAKO). Sections were then counter-stained using haematoxylin. Images were obtained using a digital sight CCD camera (DS-Fi1; Nikon, Tokyo, Japan). Semi-quantitative analyses were carried out using a computer-aided image analyzer (NIS-Elements; Nikon). Brown-stained cells in rat 
Table 1 Distribution of FR $\beta$ in normal rat tissues analyzed using flow cytometry or immunohistochemistry

\begin{tabular}{|c|c|c|}
\hline Flow Cytometric Analysis & FR $\beta$ & $\mathrm{CD} 11 \mathrm{~b} / \mathrm{c}$ \\
\hline TGC-elicited Peritoneal $m \varphi$ & $87 \pm 3.1 \%$ & $95 \pm 2.5 \%$ \\
\hline Immunohistochemical Analysis & $F R \beta$ & CD68 \\
\hline \multicolumn{3}{|l|}{ Spleen } \\
\hline White pulp & - & ++ \\
\hline 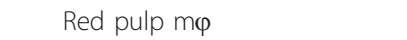 & + & +++ \\
\hline \multicolumn{3}{|l|}{ Lymph node } \\
\hline Cortex, tingible body $m \varphi$ & - & ++ \\
\hline Paracortical m $\varphi$ & - & + \\
\hline Medullary m $\varphi$ & - & + \\
\hline Subcapsular sinus me & - & + \\
\hline Brain $\mathrm{m} \varphi$ & - & + \\
\hline Liver mœ (Kupffer cells) & + & ++ \\
\hline \multicolumn{3}{|l|}{ Lung } \\
\hline Perivascular/peribronchial $\mathrm{m} \varphi$ & - & + \\
\hline Alveolar $\mathrm{m} \varphi$ & - & + \\
\hline \multicolumn{3}{|l|}{ Kidney } \\
\hline Mesangial m $\varphi$ & - & + \\
\hline \multicolumn{3}{|l|}{ Heart } \\
\hline 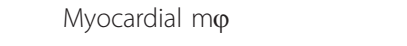 & - & + \\
\hline Endocardial $m \varphi$ & - & + \\
\hline \multicolumn{3}{|l|}{ Colon } \\
\hline \multicolumn{3}{|l|}{ Mucosa } \\
\hline 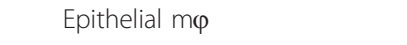 & - & + \\
\hline Lamina propria m $\varphi$ & + & + \\
\hline Muscularis mucosa me & - & + \\
\hline 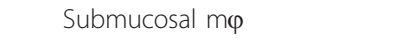 & - & + \\
\hline Muscularis externa $m \varphi$ & - & + \\
\hline
\end{tabular}

Frequency of cell staining $(-,<100 / 10$ fields), $(+, 100-200 / 10$ fields), and (++, 200-300/10 fields), (+++, >300/10 fields). Data was obtained from three normal rat tissues with similar results. FR $\beta$, folate receptor $\beta$; TGC, thioglycollate.

normal tissues and the synovial membrane and subchondral bone of ten randomly selected $\times 400$ fields from each section were counted. A color threshold mask for immunostaining was defined to detect brown color by sampling. This threshold was applied for all samples.

\section{Statistical analysis}

Statistical analyses were performed using the nonparametric Mann-Whitney $U$-test. Data are expressed as mean \pm standard error. A value of $P<0.05$ was considered statistically significant.

\section{Results}

\section{Specificity and reactivity of anti-rat $\mathrm{FR} \beta \mathrm{mAb}$}

Antibody clone 4A67 reacted with rat FR $\beta$ gene-transfected cell lines $(97.3 \pm 0.3 \%)$ but did not react with the original cell lines $(1.5 \pm 0.2 \%)$ (Figure 1A). Most TGCelicited peritoneal macrophages highly expressed FR $\beta$ $(87 \pm 3.1 \%)$ (Figure 1B and Table 1). As shown in Table
1 , the distribution of FR $\beta$ in rat tissues was similar to that in murine tissues reported previously [18]. Figure 2 shows FR $\beta$-expressing macrophages of the rat lung as an example of negative staining and the liver as an example of positive staining. E-cadherin-positive cells were observed in both tissues, indicating the presence of epithelial cells. Thus, it appears that the anti-FR $\beta$ antibody did not react with FR $\alpha$, which is known to be preferentially expressed on the apical surface of the epithelia in human lungs, kidneys, and intestinal tissues [22].

\section{Effects of dsFv anti-rat FR $\beta$ immunotoxin on apoptosis and NO production in FRß-expressing cells}

We produced recombinant dsFv anti-rat FR $\beta$ immunotoxin composed of the Fv portion of the light chain and the Fv portion of the heavy chain with PE38 as described in the Methods section. Figure 3A shows the construction of an immunotoxin and the patterns of purified $\mathrm{V}_{\mathrm{H}-\mathrm{P}} \mathrm{PE} 38$ and the immunotoxin by SDS-PAGE. A 62-kDa band and a faint lower band corresponding to the immunotoxin and a $50-\mathrm{kDa}$ band corresponding to $\mathrm{V}_{\mathrm{H}_{-}}$PE38 were observed under non-reducing conditions; 50-kDa and $12-\mathrm{kDa}$ bands of the immunotoxin were observed under reducing conditions. To assess the in vitro efficacy of this immunotoxin, we evaluated whether the immunotoxin could induce death of rat FR $\beta$ gene-transfected cells and TGC-elicited peritoneal macrophages. The immunotoxin induced death of rat FR $\beta$ gene-transfected B300-19 cells and TGC-elicited peritoneal macrophages with $\mathrm{IC}_{50}$ values of $10 \mathrm{ng} / \mathrm{mL}$ and $100 \mathrm{ng} / \mathrm{mL}$, respectively, but did not change that of the original B300-19 cells (Figure 3B and $3 \mathrm{C}$ ). Additionally, the immunotoxin suppressed $\mathrm{NO}$ production by peritoneal macrophages activated using IFN $-\gamma$ and LPS at lower concentrations $(35.4 \pm 2.1 \mathrm{ng} / \mathrm{mL}$ at $50 \%$ suppression) than those inducing cell death (Figure 3D).

\section{Suppression of joint swelling of arthritis by dsFv anti-FR $\beta$ immunotoxin}

A previous study showed infiltration of macrophages in the synovium of AIA [23]. Similarly, we observed peak infiltration of FR $\beta$-expressing macrophages in arthritic synovium from days five through seven (Figure 4A). Arthritic joints were treated intra-articularly using three different doses of immunotoxin. These treatments reduced joint swelling over the course of therapy in a dose-dependent manner compared to that using the control protein $\left(\mathrm{V}_{\mathrm{H}^{-}} \mathrm{PE} 38\right)$ (Figure 4B). Treatment with medium and high doses resulted in a reduction in joint swelling even at 14 days post-injection. The degree of suppression was $26.7 \pm 3.2 \%(P<0.05)$ at the medium dose and $61.6 \pm$ $3.4 \%(P<0.01)$ at the high dose compared to the control on day 21 . Body weight was $174 \pm 4 \mathrm{~g}$ (rats treated with control) and $173 \pm 5 \mathrm{~g}$ (rats treated with high-dose 

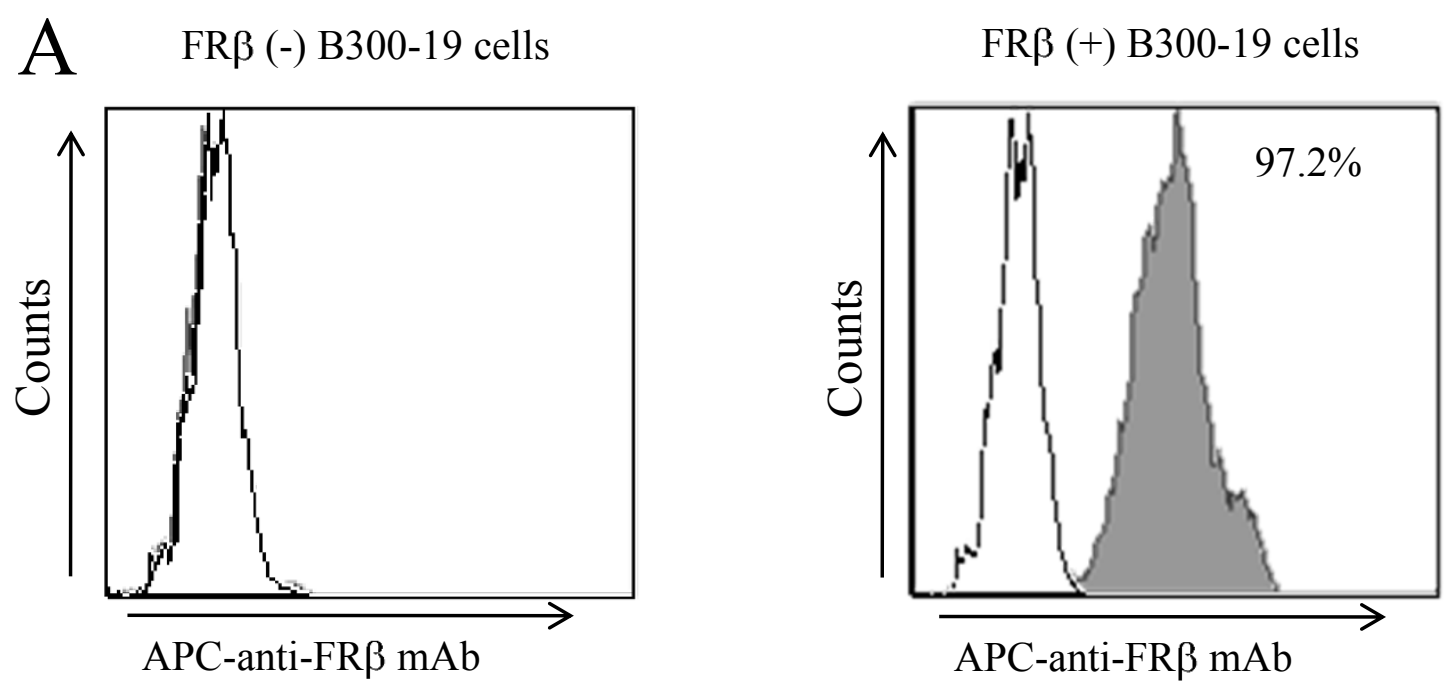

$\mathrm{B}$
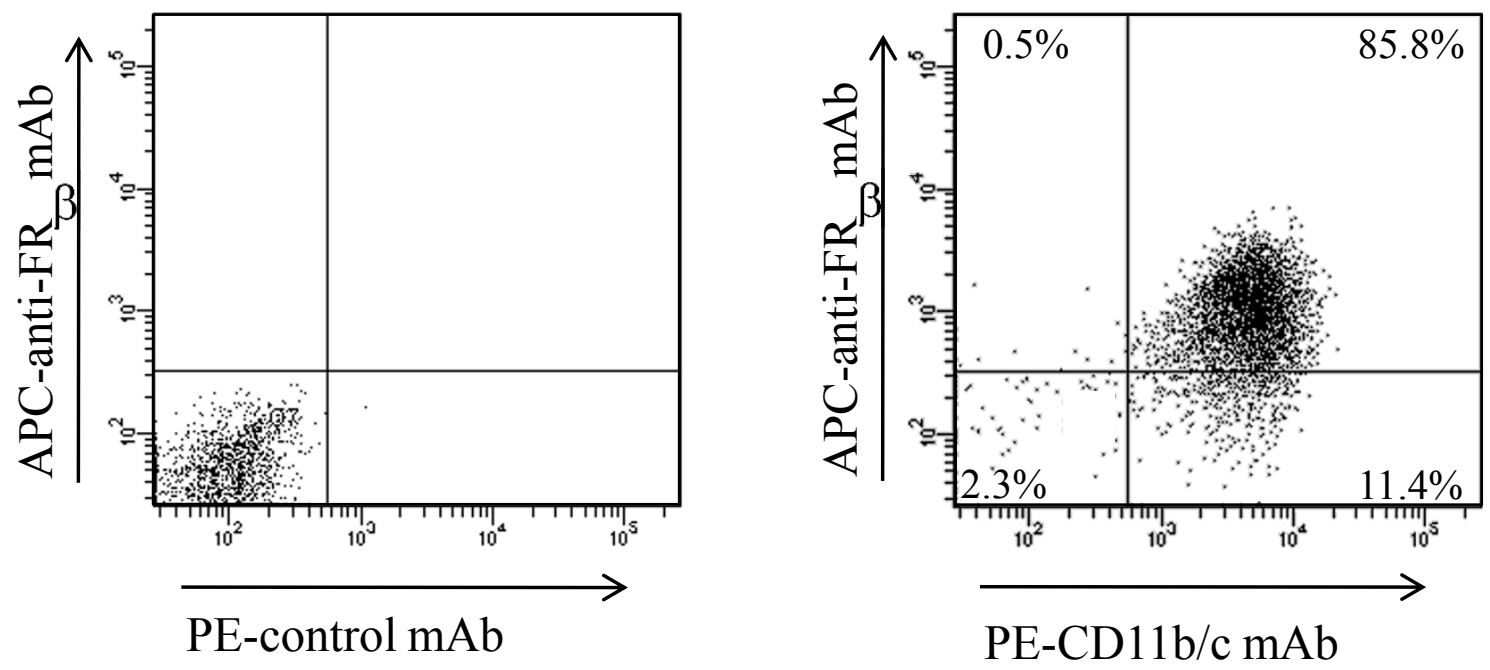

Figure 1 Reactivity of an anti-rat FR $\beta$ mAb with FR $\beta$-expressing cells. (A) Non-transfected B300-19 cells (left) and rat FR gene-transfected B30019 cells. (right) were stained using an anti-rat FRß (4A67) mAb (black pattern) or isotype-matched irrelevant mAb (white pattern). Stained cells were analyzed using flow cytometry. Data are representative of three separate experiments. (B) TGC-elicited macrophages were double-stained using an anti-FRß mAb (4A67) and PE-conjugated CD11b/c mAbs (OX42) and analyzed using flow cytometry. Numbers represent the percentage of cells within designated gates. Data are representative of three separate experiments. FR $\beta$, folate receptor $\beta$; mAb, monoclonal antibody; TGC, thioglycollate.

immunotoxin) on day 0 , and $203 \pm 8 \mathrm{~g}$ (rats treated with control) and $198 \pm 11 \mathrm{~g}$ (rats treated with high-dose immunotoxin) on day 21. Changes in body weight between the groups were not significant at any time points.

\section{Improvement in histological scores in arthritic joints following intra-articular administration of dsFv anti-FR $\beta$ immunotoxin}

Histopathological evaluation was performed at the end of the study (day 21). As shown in Figure 5A and 5B, arthritic joints treated using medium and high doses showed lower grades of inflammation, synovial membrane thickness, and cartilage and bone destruction compared to those with control protein treatment or treatment with a low dose of immunotoxin. The effects of immunotoxin were prominent with regard to histological scores, indicating cartilage and bone destruction (scores of rats treated with control versus immunotoxin; $2.2 \pm 0.2$ versus $0.5 \pm$ $0.1, P<0.01)$. Thus, we determined the numbers of synovial macrophages, FR $\beta$-expressing macrophages, and cathepsin K-positive cells, which are osteoclast precursors 

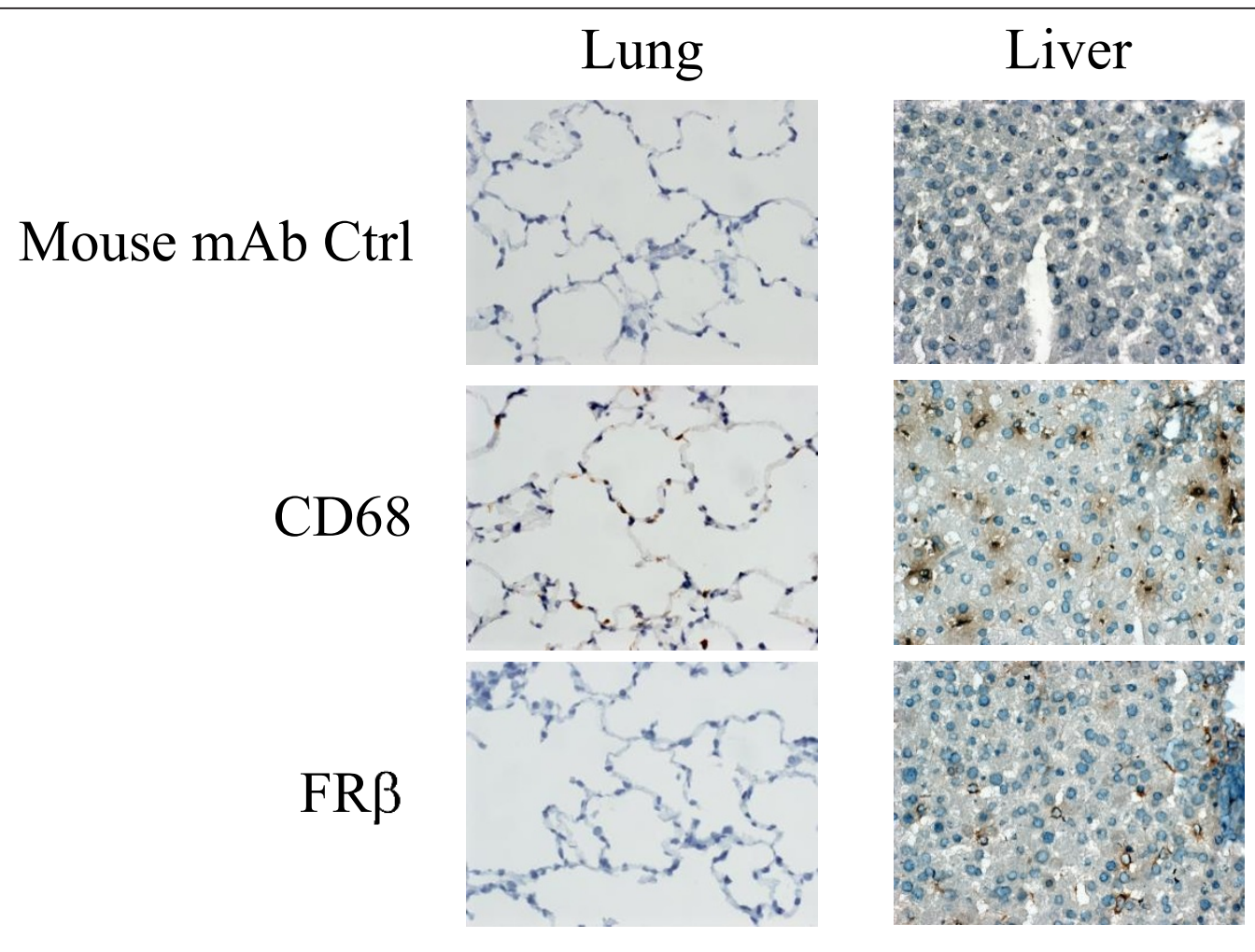

\section{Biotinylated - $\mathrm{Ab}$ ctrl}

\section{E-cadherin}
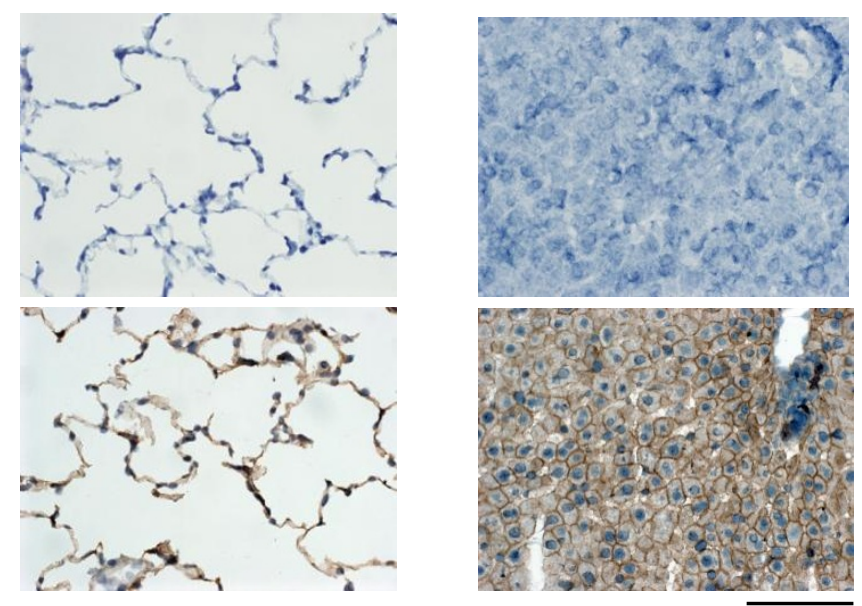

$0.1 \mathrm{~mm}$

Figure 2 Reactivity of an anti-rat FR $\beta$ mAb with rat lung and liver tissues. Lung and liver tissues from normal rats were stained using antibodies against CD68, FRß, or E-cadherin. Photographs are representative of CD68-, FRß-, and E-cadherin staining in lung or liver tissues of three rats per group. Note that FRB-positive cells were observed in the liver but not in the lung. CD68- positive cells and E-cadherin-positive cells (indicating the presence of epithelial cells) were observed in both tissues; original magnification was $\times 400$. FR $\beta$, folate receptor $\beta$; mAb, monoclonal antibody.

or osteoclasts in synovial and subchondrial regions. Immunohistological analysis revealed that high-dose treatment reduced these numbers, particularly with regard to the numbers of FR $\beta$-expressing macrophages and cathepsin $\mathrm{K}$-positive cells, compared to that with the control protein (Figure 6A and 6B). 
A

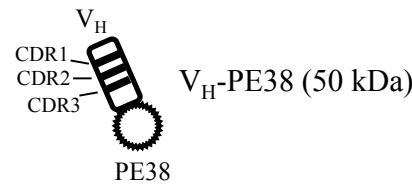

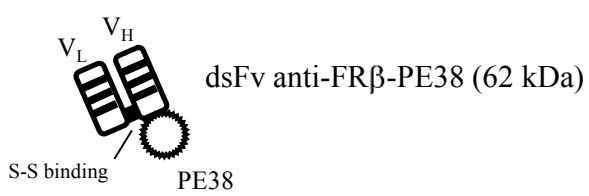

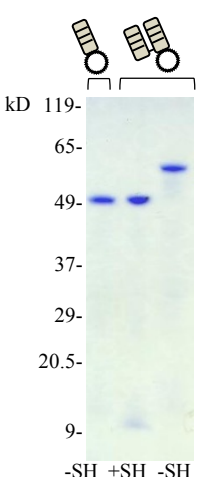

dsFv anti-FR $\beta$-PE38 (72h)
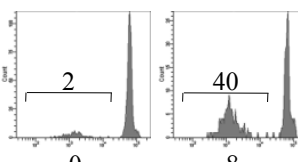

$\mathrm{V}_{\mathrm{H}^{-}}-\mathrm{PE} 38(72 \mathrm{~h})$
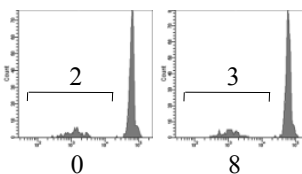

8

8

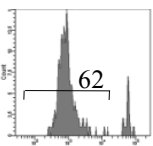

40
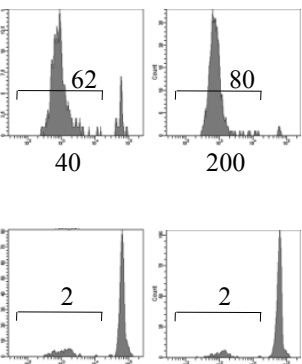

40

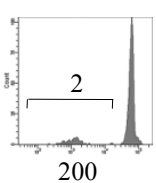

Concentrations $(\mathrm{ng} / \mathrm{ml})$

Concentrations of recombinant immunotoxin $(\mathrm{ng} / \mathrm{ml})$

$\mathrm{D}$

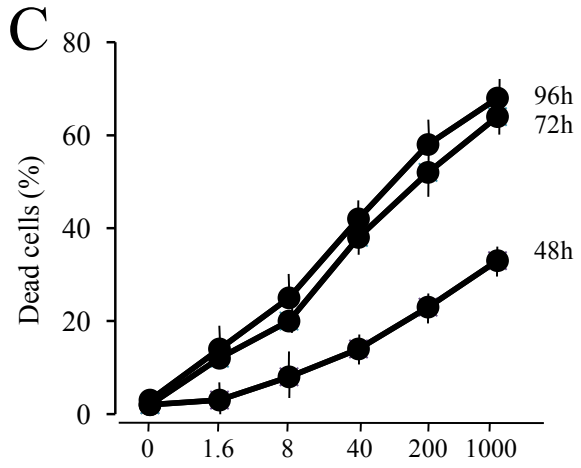

Concentrations of recombinant immunotoxin $(\mathrm{ng} / \mathrm{ml})$

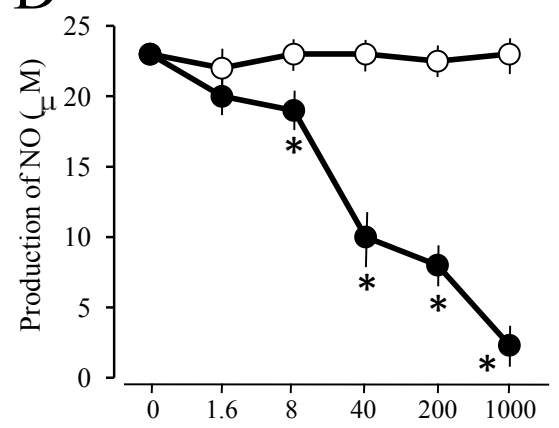

Concentrationsof recombinant immunotoxin (ng/ml)

Figure 3 Effects of anti-FR $\boldsymbol{\beta}$ immunotoxin on cell death induction and NO production of FR $\boldsymbol{\beta}$-expressing cells. (A)The schema shows the construction of $\mathrm{V}_{\mathrm{H}^{-}} \mathrm{PE} 38$ and $\mathrm{dsFv}$ anti-FR $\beta$-PE38. The purity of $\mathrm{V}_{\mathrm{H}^{-}} \mathrm{PE} 38$ and dsFv anti-FR $\beta$-PE38 were analyzed using sodium dodecyl sulphate$6 \%$ to $15 \%$ gradient gel electrophoresis in non-reducing $(-\mathrm{SH})$ and reducing conditions $(+\mathrm{SH})$. Molecular weight markers are shown at left. (B) Rat FR $\beta$-transfected B300-19 cells were cultured at the indicated concentrations of $\mathrm{V}_{\mathrm{H}^{-}} \mathrm{PE} 38$ (open triangle) for 72 hours or at the indicated concentrations of dsFv anti-FRß-PE38 (filled circle) for 36, 48, or 72 hours. Non-transfected B300-19 cells were also cultured at the indicated concentrations of dsFv anti-FR $\beta$-PE38 (open circle) for 36, 48, or 72 hours. The number of dead cells was measured using propidium iodide staining and flow cytometric analysis, and the percentage of dead cells was calculated as the number of dead cells divided by total cell number. Values are the mean \pm SEM of induced cell death from three separate experiments. The right panels are representative of propidium iodide staining patterns at the indicated concentrations of $V_{H^{-}}$PE38 or dsFv anti-FR $\beta$-PE38. Values in panels show the percentages of dead cells. (C) Thioglycollate-elicited macrophages were cultured at the indicated concentrations of $V_{H^{-}}$PE38 or dsFv anti-FR 3 -PE38 for 48 , 72 , or 96 hours. Induced cell death (\%) was determined by subtracting the percentage of dead cells induced by $V_{H^{-}}$PE38 from that induced by dsFV anti-FR $\beta$ PE38 in each sample. Values are the mean \pm SEM of induced cell death of three separate experiments. (D) Thioglycollate-elicited macrophages were cultured at the indicated concentrations of $V_{H^{-}}$PE38 (open circle) or dsFv anti-FRß-PE38 (filled circle) for 24 hours and stimulated using IFN$\gamma$ and LPS for an additional 48 hours. $\mathrm{NO}$ in the supernatants was measured using the Griess reaction. Values are the mean \pm SEM of three separate experiments. ${ }^{*} P<0.05$ compared to the $V_{H^{-}}$PE38 group. FR $\beta$, folate receptor $\beta$; IFN- $\gamma$, interferon- $\gamma$; LPS, Lipopolysaccharide; SEM, standard error of the mean. 


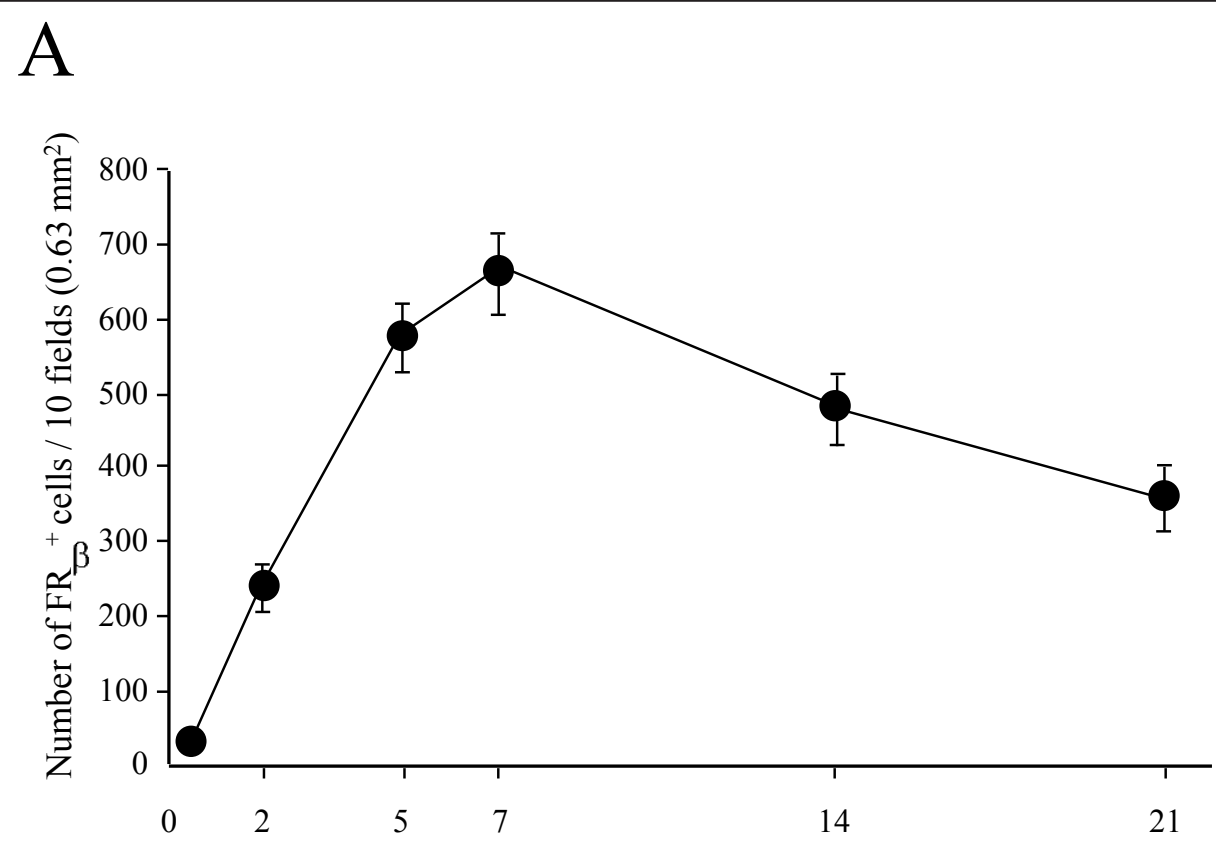

Days after AIA

$\mathrm{B}$

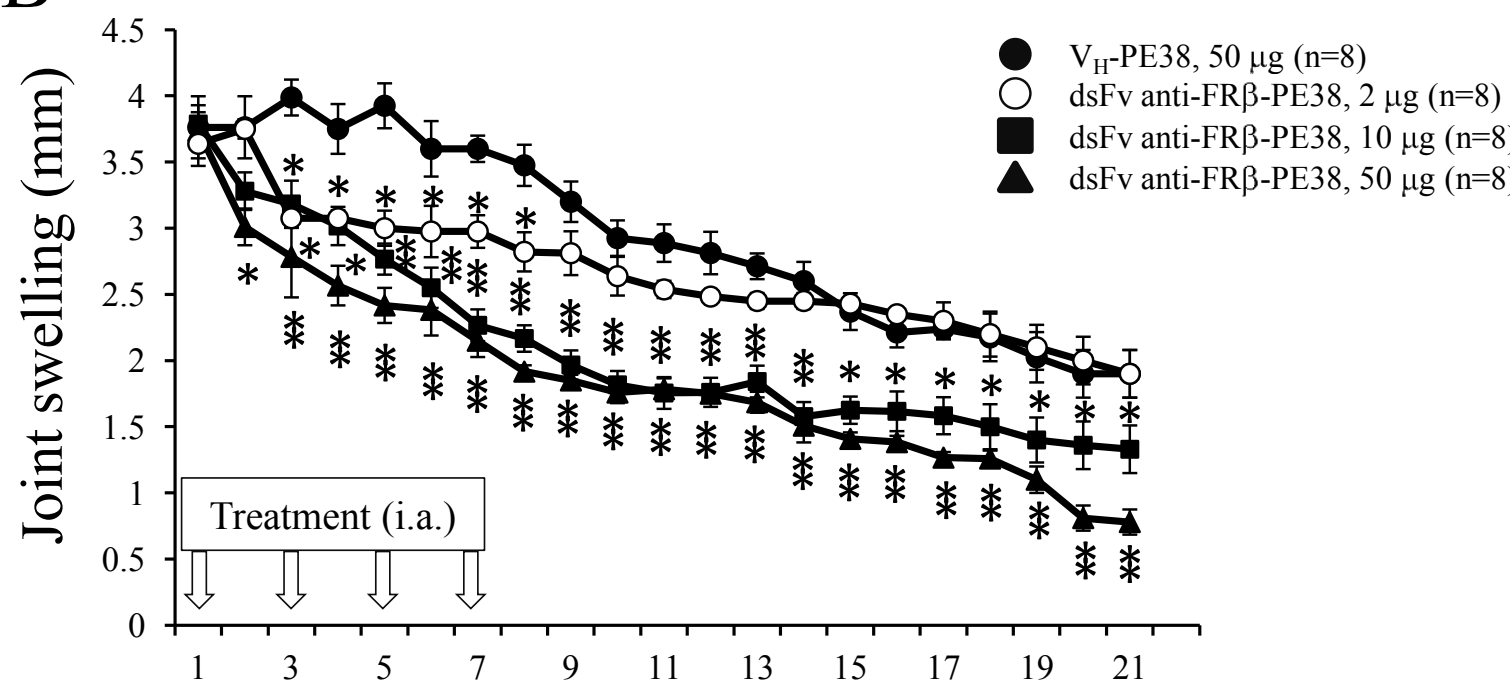

Days after treatment

Figure 4 Effects of anti-FR $\boldsymbol{\beta}$ immunotoxin on knee joint swelling in rat AIA. (A) FR $\boldsymbol{\beta}$-expressing macrophages in synovium of the arthritis rat were examined on the indicated days after AIA onset as described in Methods. Values are the mean \pm SEM of knee joints from four rats per group. (B) AIA was induced using intra-articular injection of methylated BSA as described in Methods. Arthritic rats were injected in the left knee joint with $50 \mu \mathrm{g}$ of $\mathrm{V}_{\mathrm{H}_{-}} \mathrm{PE} 38$ (filled circle) or with $2 \mu \mathrm{g}$ (open circle), $10 \mu \mathrm{g}$ (filled square) or $50 \mu \mathrm{g}$ (filled triangle) of dsFv anti-FRß-PE38 on days one, three, five and seven. Knee joint swelling was measured for each rat by measuring the difference in diameter between the arthritic left knee and the normal right knee. Values are the mean \pm SEM of knee joint swelling from eight rats per group. ${ }^{*} P<0.05$ and ${ }^{*} P<0.01$ compared

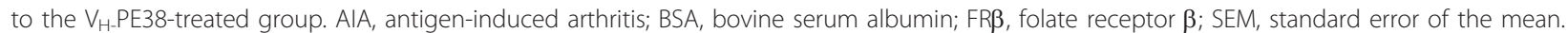




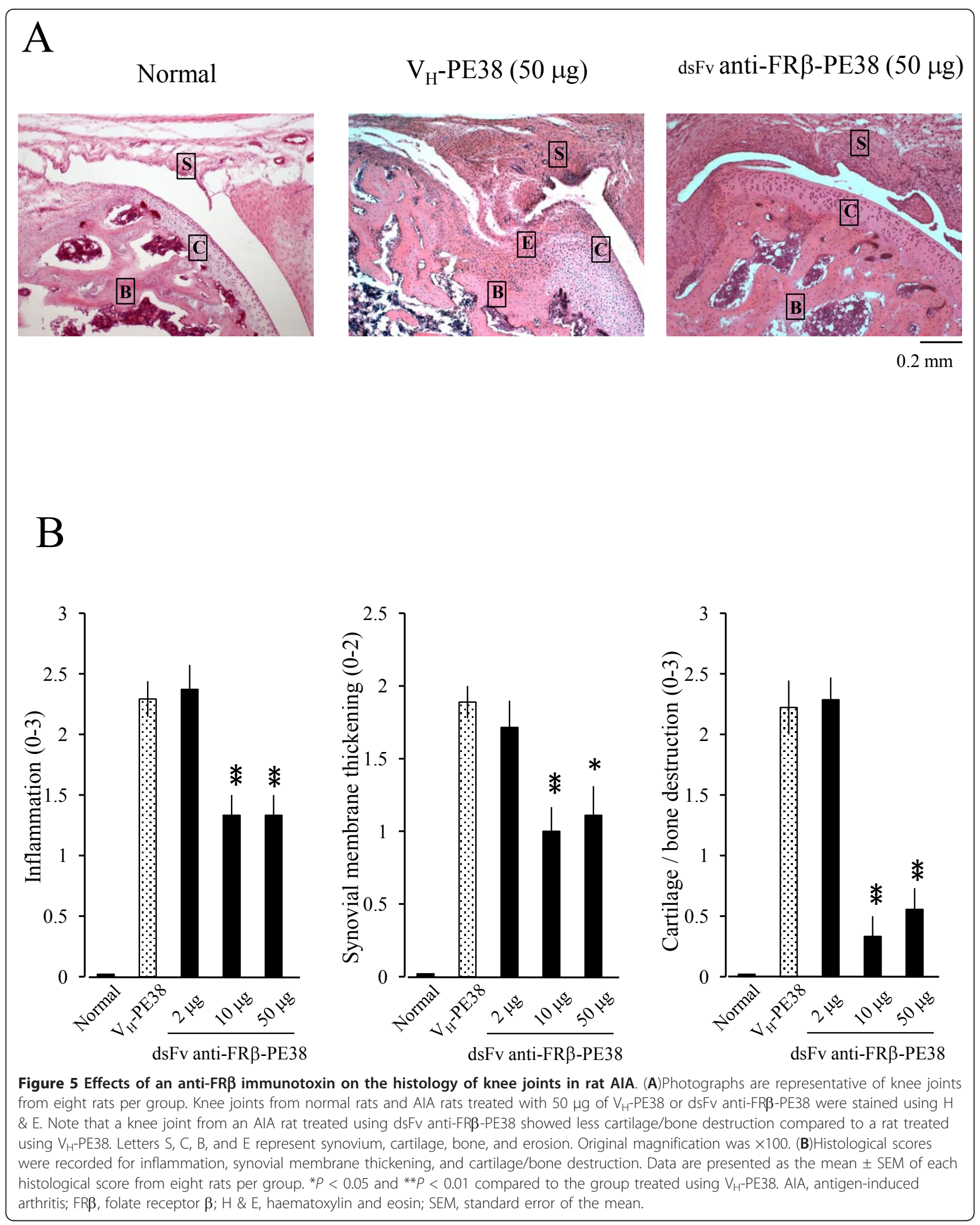




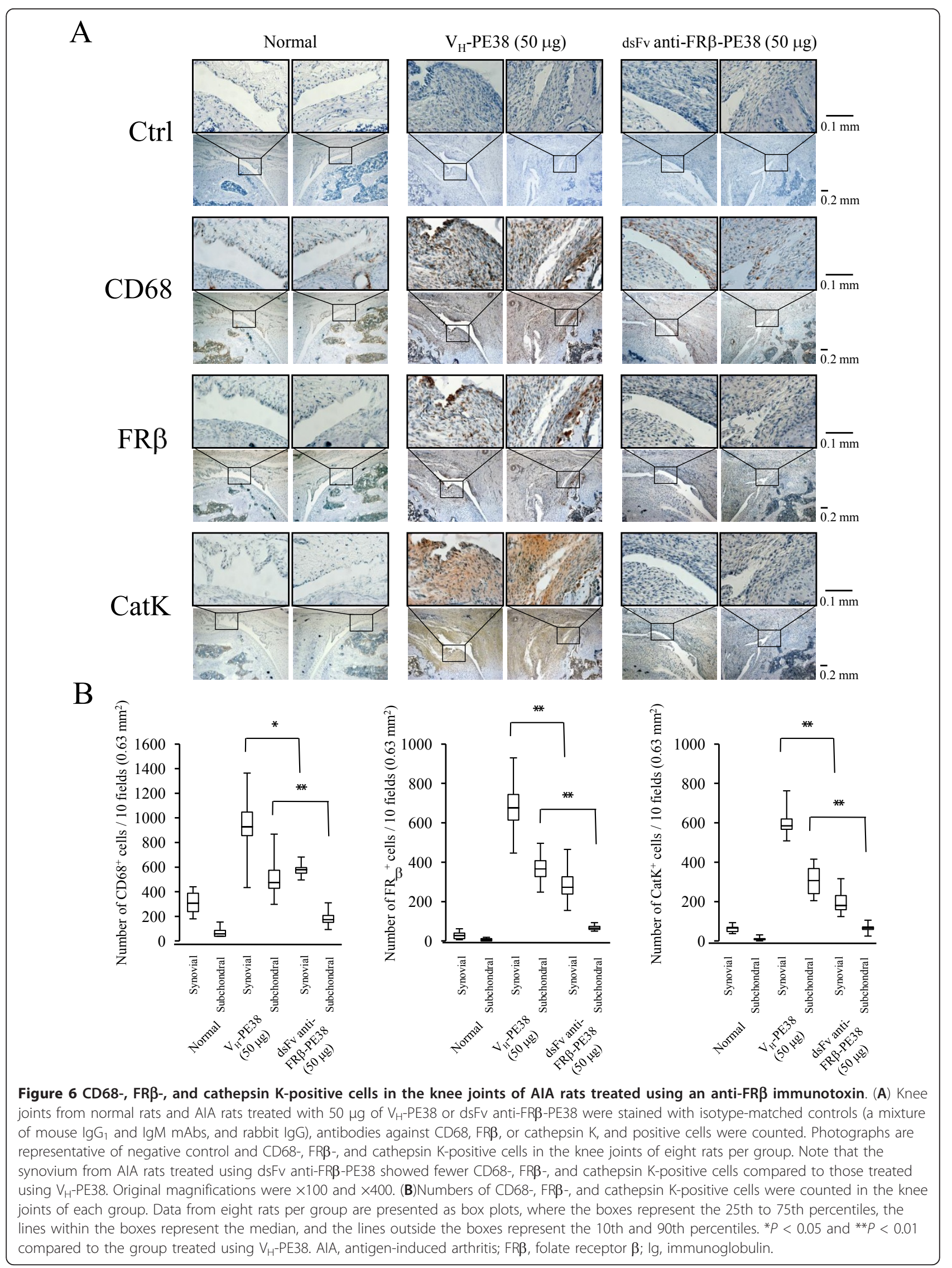




\section{Discussion}

We produced an anti-rat FR- $\beta$ mAb and its dsFv recombinant immunotoxin consisting of the $\mathrm{Fv}$ portion of an anti-FR $\beta \mathrm{mAb}$ and PE38. Using this antibody, it was previously demonstrated that expression and distribution of FR $\beta$-expressing macrophages in rat tissues were similar to those in murine tissues in which FR $\beta$-expressing macrophages are rarely present [18]. After the onset of mBSA-induced arthritis, intra-articular injections of immunotoxin reduced joint swelling during the acute phase of arthritis. Antigen-induced arthritis shows several clinical and histopathological similarities to human RA. Its maximal clinical activity, two to three days postinduction, chronic arthritis develops, characterized by synovial hyperplasia, inflammatory inflammation, and cartilage and bone destruction [24]. Destruction of cartilage matrix results predominantly from the action of connective tissue proteinase released by RA synovial tissues, chondrocytes, and pannus tissues. Several lines of evidence in RA and animal models of arthritis support a role for osteoclasts in the pannus tissue in the pathogenesis of bone erosions. RA synovial tissues, including macrophages, fibroblasts, and $\mathrm{T}$ cells, produce a variety of cytokines and growth factors that may increase osteoclast formation, activity, and/or survival. Specifically, the interaction of the receptor activator of nuclear factorkappaB ligand (RANKL) produced by fibroblasts and $\mathrm{T}$ cells on RANK on osteoclast precursors is critical for inducing the differentiation of cells of the monocyte/ macrophage lineage into osteoclasts [25]. We previously observed that most osteoclasts originate from FR $\beta$ expressing macrophages in RA synovial culture and that administration of dsFv anti-FR $\beta$-PE38 reduced the number of activated fibroblasts and macrophages in RA synovial tissue engrafted into SCID mice [8]. Thus, removal of macrophages using the immunotoxin may reduce the number of osteoclast precursors and osteoclasts, protecting against cartilage and bone destruction in arthritis.

Findings in rat arthritis models indicate that osteoclasts are formed soon after the onset of clinical arthritis and are continuously replenished by infiltrating macrophages during disease progression [26]. Thus, early and effective blockade of osteoclastogenesis may be accomplished by targeting infiltrated macrophages. In this study, we showed that intra-articular injection of medium- and high-dose immunotoxins reduced the number of FR $\beta$ expressing macrophages, even at 14 days post-injection. Several studies have demonstrated that systemic administration of FR-mediated drugs is effective for reducing the activity of experimental arthritis [9,11,27-29]; however, it remains unknown whether intra-articular administration of these drugs is effective for treating arthritic joints. This is the first study demonstrating that intra-articular injections targeting FR $\beta$-expressing macrophages are efficacious as local therapy.

Intra-articular injections of corticosteroids or hyaluronate are generally available for treating mono and oligoarthritis $[14,15,30]$. Although these treatments appear to be safe and beneficial, the reduction in pain and inflammation is only temporary. Consistent with these clinical outcomes, it has been reported that macrophage infiltration and proinflammatory endothelial cytokine expression remained unchanged in arthroscopic biopsies of RA synovial tissues after intra-articular administration of corticosteroids [31]. Additionally, intra-articular administration of high-molecular weight hyaluronate promoted joint swelling, inflammation, and cartilage damage during the late chronic phase of mBSA-induced arthritis [32]. Thus, intra-articular injections of immunotoxin appear to be effective for improving long-term effects compared to the use of corticosteroids and hyaluronate. Several studies have demonstrated that intraarticular injections of anti-TNF biologics are effective for treating RA or experimental arthritic joints, although cumulative data of intra-articular administration of available biologics to RA joints show inconsistent levels of effectiveness $[17,33]$. Additionally, local therapy using anti-TNF biologics has not been evaluated in arthritis refractory to systemic anti-TNF therapy because many patients in successful cases were naïve to systemic antiTNF biologics. Experimental studies have demonstrated that anti-TNF biologics are capable of binding membranous TNF on macrophages and mediate antibody-dependent cell-mediated cytotoxicity and complementdependent cytotoxicity $[34,35]$. An anti-FR $\beta$ immunotoxin induces apoptosis of FR $\beta$-expressing macrophages by PE38 to inhibit protein synthesis by elongation factor 2 [36]. However, we did not find a significant difference of ratios of apoptotic cells detected by tunnel staining in synovial macrophages between treated and non-treated synovium on day21 (data not shown). We speculate that apoptotic cells induced by the immunotoxin may be removed during the 14 days that had passed since the last injection Thus, intra-articular injection of immunotoxin may be useful for treating arthritis refractory to systemic anti-TNF therapy. Cartilage penetration by proteins is dependent on a protein's molecular weights and charges; full-length IgG cannot penetrate cartilage [37]. The dsFv anti-FR $\beta$ immunotoxin is of lower molecular weight $(62 \mathrm{kDa})$ than full-length IgG, allowing higher penetration into synovial tissues than full-length IgG. Interestingly, single-chain Fv anti-TNF $\alpha$ mAb inhibited acute inflammation of the knee joint induced by intra-articular administration of recombinant human TNF- $\alpha$, although this model was not directly representative of RA. Conversely, a lower molecular weight may 
have a lower half-life and fewer prolonged effects [38]. In fact, we did not detect the immunotoxin in sera and synovium from treated mice on the last day (data not shown). These results are reasonable because it was reported that the half-life of DsFv-PE38 immunotoxin in sera is less than 30 minutes [39].

To increase retention time in joints, intra-articular injections of immunotoxins using nanoparticles and/or liposomes may be beneficial for clinical application [40]. Clinical studies have shown that immunotoxins based on PE38 show lower nonspecific toxicity but retain antigen-dependent toxicity towards target cells [41]. Local injection can generally be effective at lower doses than systemic injection. Thus, intra-articular administration of immunotoxin may overcome several challenges, including non-specific cytotoxicity and immunogenicity resulting from systemic usage of the immunotoxin.

\section{Conclusions}

Intra-articular administration of an immunotoxin to FR $\beta$ was effective for improving rat antigen-induced arthritis. This treatment may provide a new strategy for targeting limited arthritis with rheumatoid arthritis in which FR $\beta$ expressing macrophages are abundant.

\footnotetext{
Abbreviations

AIA: antigen-induced arthritis; BSA: bovine serum albumin; FCS: fetal calf serum; FR: folate receptor; Fv: fragment of Ig consisting of heavy: light chain variable domains; $\mathrm{H}$ \& E: haematoxylin and eosin; IFN: interferon; Ig: immunoglobulin; IMDM: Iscove's Modified Dulbecco's medium; mAb: monoclonal antibody; PBS: phosphate-buffered saline; PE38: truncated Pseudomonas exotoxin-A - should be removed; RA: rheumatoid arthritis; RANKL: receptor activator of nuclear factor-kappaB ligand; RT-PCR: reverse transcriptase-polymerase chain reaction; SCID: severe combined immunodeficiency; TGC: thioglycollate; TNF: tumor necrosis factor; $V_{H}$ : heavy chain variable domain; $V_{L}$ : light chain variable domain;
}

\section{Acknowledgements}

This work was also supported in part by Grants-in-Aid for Scientific Research from MEXT (KAKENHI) (23592134, to TN; 23591441, to TM).

\section{Author details}

${ }^{1}$ Department of Immunology, Graduate school of Medical and Dental Sciences, Kagoshima University, Kagoshima 890-8544, Japan. ${ }^{2}$ Cancer and Regenerative Medicine, Frontier Science Research Center, Kagoshima University Graduate School of Medical and Dental Sciences, Kagoshima 8908544, Japan.

\section{Authors' contributions}

TN and AK carried out animal experiments, and statistical analysis. TN, KH and TM carried out the immunohistology and statistical analysis. TN, AK, KH, ST, and TM participated in the design and analysis of the study and helped to draft the manuscript. All authors read and approved the final manuscript.

\section{Competing interests}

The authors declare that they have no competing interests.

Received: 20 October 2011 Revised: 2 April 2012 Accepted: 2 May 2012 Published: 2 May 2012

\section{References}

1. Szekanecz Z, Koch AE: Macrophages and their products in rheumatoid arthritis. Curr Opin Rheumatol 2007, 19:289-295.

2. McHugh KP, Shen Z, Crotti TN, Flannery MR, O'Sullivan RP, Purdue PE, Goldring SR: The role of cell-substrate interaction in regulating osteoclast activation: potential implications in targeting bone loss in rheumatoid arthritis. Ann Rheum Dis 2010, 69(Suppl 1):i83-85.

3. Mulherin D, Fitzgerald O, Bresnihan B: Synovial tissue macrophage populations and articular damage in rheumatoid arthritis. Arthritis Rheum 1996, 39:115-124.

4. Tak PP, Smeets TJ, Daha MR, Kluin PM, Meijers KA, Brand R, Meinders AE, Breedveld C: Analysis of the synovial cell infiltrate in early rheumatoid synovial tissue in relation to local disease activity. Arthritis Rheum 1997, 40:217-225.

5. Bresnihan B, Pontifex E, Thurlings RM, Vinkenoog M, El-Gabalawy $H_{\text {, }}$ Fearon U, Fitzgerald O, Gerlag DM, Rooney T, van de Sande MG, Veale D, Vos K, Tak PP: Synovial tissue sublining CD68 expression is a biomarker of therapeutic response in rheumatoid arthritis clinical trials: consistency across centers. J Rheumatol 2009, 36:1800-1802.

6. Nakashima-Matsushita N, Homma T, Yu S, Matsuda T, Sunahara N, Nakamura T, Tsukano M, Ratnam M, Matsuyama T: Selective expression of folate receptor beta and its possible role in methotrexate transport in synovial macrophages from patients with rheumatoid arthritis. Arthritis Rheum 1999, 42:1609-1616.

7. Nagayoshi R, Nagai T, Matsushita K, Sato K, Sunahara N, Matsuda T, Nakamura T, Komiya S, Onda M, Matsuyama T: Effectiveness of anti-folate receptor beta antibody conjugated with truncated Pseudomonas exotoxin in the targeting of rheumatoid arthritis synovial macrophages. Arthritis Rheum 2005, 52:2666-2675.

8. Tsuneyoshi Y, Tanaka M, Nagai T, Sunahara N, Matsuda T, Sonoda T, Ijiri K, Komiya S, Matsuyama T: Functional folate receptor beta-expressing macrophages in osteoarthritis synovium and their M1/M2 expression profiles. Scand J Rheumatol 2012, 41:132-140.

9. Nagai T, Tanaka M, Tsuneyoshi $Y$, Matsushita $K$, Sunahara N, Matsuda T, Yoshida H, Komiya S, Onda M, Matsuyama T: In vitro and in vivo efficacy of a recombinant immunotoxin against folate receptor beta on the activation and proliferation of rheumatoid arthritis synovial cells. Arthritis Rheum 2006, 54:3126-3134.

10. van der Heijden JW, Oerlemans R, Dijkmans BA, Qi H, van der Laken CJ, Lems WF, Jackman AL, Kraan MC, Tak PP, Ratnam M, Jansen G: Folate receptor beta as a potential delivery route for novel folate antagonists to macrophages in the synovial tissue of rheumatoid arthritis patients. Arthritis Rheum 2009, 60:12-21.

11. Lu Y, Stinnette TW, Westrick E, Klein PJ, Gehrke MA, Cross VA, Vlahov IR, Low PS, Leamon CP: Treatment of experimental adjuvant arthritis with a novel folate receptor-targeted folic acid-aminopterin conjugate. Arthritis Res Ther 2011, 13:R56.

12. Sidiropoulos P, Bertsias G, Kritikos HD, Kouroumali H, Voudouris K, Boumpas DT: Infliximab treatment for rheumatoid arthritis, with dose titration based on the Disease Activity Score: dose adjustments are common but not always sufficient to assure sustained benefit. Ann Rheum Dis 2004, 63:144-148.

13. Aly MN: Intra-articular drug delivery: a fast growing approach. Recent Pat Drug Deliv Formul 2008, 2:231-237.

14. Konai MS, Vilar Furtado RN, Dos Santos MF, Natour J: Monoarticular corticosteroid injection versus systemic administration in the treatment of rheumatoid arthritis patients: a randomized double-blind controlled study. Clin Exp Rheumatol 2009, 27:214-221.

15. Habib GS, Saliba W, Nashashibi M: Local effects of intra-articular corticosteroids. Clin Rheumatol 2010, 29:347-356

16. Goetz M, Klug S, Gelse K, Swoboda B, Carl HD: Combined arthroscopic and radiation synovectomy of the knee joint in rheumatoid arthritis: 14-year follow-up. Arthroscopy 2011, 27:52-59.

17. Fisher BA, Keat A: Should we be using intraarticular tumor necrosis factor blockade in inflammatory monoarthritis? J Rheumatol 2006, 33:1934-1935.

18. Nagai T, Tanaka M, Tsuneyoshi Y, Xu B, Michie SA, Hasui K, Hirano H, Arita K, Matsuyama T: Targeting tumor-associated macrophages in an experimental glioma model with a recombinant immunotoxin to folate receptor beta. Cancer Immunol Immunother 2009, 58:1577-1586. 
19. Richards PJ, Williams AS, Goodfellow RM, Williams BD: Liposomal clodronate eliminates synovial macrophages, reduces inflammation and ameliorates joint destruction in antigen-induced arthritis. Rheumatology (Oxford) 1999, 38:818-825.

20. Williams AS, Camilleri JP, Goodfellow RM, Williams BD: A single intraarticular injection of liposomally conjugated methotrexate suppresses joint inflammation in rat antigen-induced arthritis. Br J Rheumatol 1996, 35:719-724.

21. Kawamoto T: Use of a new adhesive film for the preparation of multipurpose fresh-frozen sections from hard tissues, whole-animals, insects and plants. Arch Histol Cytol 2003, 66:123-143.

22. Hilgenbrink AR, Low PS: Folate receptor-mediated drug targeting: from therapeutics to diagnostics. J Pharm Sci 2005, 94:2135-2146.

23. Beckmann N, Falk R, Zurbrügg S, Dawson J, Engelhardt P: Macrophage infiltration into the rat knee detected by MRI in a model of antigeninduced arthritis. Magn Reson Med 2003, 49:1047-1055.

24. Brauer R, Kette H, Henzgen S, Thoss K: Influence of cyclosporin A on cytokine levels in synovial fluid and serum of rats with antigen-induced arthritis. Agents Actions 1994, 41:96-98.

25. Gravallese EM, Manning C, Tsay A, Naito A, Pan C, Amento E, Goldring SR: Synovial tissue in rheumatoid arthritis is a source of osteoclast differentiation factor. Arthritis Rheum 2000, 43:250-258.

26. Schett G, Stolina M, Bolon B, Middleton S, Adlam M, Brown H, Zhu L, Feige $U$, Zack DJ: Analysis of the kinetics of osteoclastogenesis in arthritic rats. Arthritis Rheum 2005, 52:3192-3201.

27. Paulos CM, Varghese B, Widmer WR, Breur GJ, Vlashi E, Low PS: Folatetargeted immunotherapy effectively treats established adjuvant and collagen-induced arthritis. Arthritis Res Ther 2006, 8:R77.

28. Thomas TP, Goonewardena SN, Majoros IJ, Kotlyar A, Cao Z, Leroueil PR, Baker JR Jr: Folate-targeted nanoparticles show efficacy in the treatment of inflammatory arthritis. Arthritis Rheum 2011, 63:2671-2680.

29. Fernandes JC, Wang H, Jreyssaty C, Benderdour M, Lavigne P, Qiu X Winnik FM, Zhang X, Dai K, Shi Q: Bone-protective effects of nonviral gene therapy with folate-chitosan DNA nanoparticle containing interleukin-1 receptor antagonist gene in rats with adjuvant-induced arthritis. Mol Ther 2008, 16:1243-1251.

30. Saito S, Kotake S: Is there evidence in support of the use of intra-articular hyaluronate in treating rheumatoid arthritis of the knee? A metaanalysis of the published literature. Mod Rheumatol 2009, 19:493-501.

31. af Klint E, Grundtman C, Engstrom M, Catrina Al, Makrygiannakis D, Klareskog L, Andersson U, Ulfgren AK: Intraarticular glucocorticoid treatment reduces inflammation in synovial cell infiltrations more efficiently than in synovial blood vessels. Arthritis Rheum 2005, 52:3880-3889.

32. Roth A, Mollenhauer J, Wagner A, Fuhrmann $R$, Straub A, Venbrocks RA Petrow P, Bräuer R, Schubert H, Ozegowski J, Peschel G, Müller PJ, Kinne RW: Intra-articular injections of high-molecular-weight hyaluronic acid have biphasic effects on joint inflammation and destruction in rat antigen-induced arthritis. Arthritis Res Ther 2005, 7:R677-686.

33. Conti F, Ceccarelli F, Priori R, lagnocco A, Signore A, Valesini G: Intraarticular infliximab in patients with rheumatoid arthritis and psoriatic arthritis with monoarthritis resistant to local glucocorticoids. Clinical efficacy extended to patients on systemic anti-tumour necrosis factor alpha. Ann Rheum Dis 2008, 67:1787-1790

34. Beenhouwer D, Wallis R, Broder M, Furst DE: Mechanisms of action of tumor necrosis factor antagonist and granulomatous infections. $J$ Rheumatol 2004, 31:1888-1892.

35. Catrina Al, Trollmo C, af Klint E, Engstrom M, Lampa J, Hermansson $Y$, Klareskog L, Ulfgren AK: Evidence that anti-tumor necrosis factor therapy with both etanercept and infliximab induces apoptosis in macrophages, but not lymphocytes, in rheumatoid arthritis joints: extended report. Arthritis Rheum 2005, 52:61-72.

36. Keppler-Hafkemeyer A, Brinkmann U, Pastan I: Role of caspases in immunotoxin-induced apoptosis of cancer cells. Biochemistry 1998, 37:16934-16942

37. Urech DM, Feige U, Ewert S, Schlosser V, Ottiger M, Polzer K, Schett G, Lichtlen P: Anti-inflammatory and cartilage-protecting effects of an intraarticularly injected anti-TNF\{alpha\} single-chain Fv antibody (ESBA105) designed for local therapeutic use. Ann Rheum Dis 2010, 69:443-449.
38. Butoescu N, Jordan O, Doelker E: Intra-articular drug delivery systems for the treatment of rheumatic diseases: a review of the factors influencing their performance. Eur J Pharm Biopharm 2009, 73:205-218.

39. Bang S, Nagata S, Onda M, Kreitman RJ, Pastan I: HA22 (R490A) is a recombinant immunotoxin with increased antitumor activity without an increase in animal toxicity. Clin Cancer Res 2005, 11:1545-1550.

40. Burt HM, Tsallas A, Gilchrist S, Liang LS: Intra-articular drug delivery systems: Overcoming the shortcomings of joint disease therapy. Expert Opin Drug Deliv 2009, 6:17-26.

41. Kreitman RJ: Recombinant immunotoxins containing truncated bacterial toxins for the treatment of hematologic malignancies. BioDrugs 2009, 23:1-13.

doi:10.1186/ar3831

Cite this article as: Nagai et al:: Efficacy of an immunotoxin to folate receptor beta in the intra-articular treatment of antigen-induced arthritis. Arthritis Research \& Therapy 2012 14:R106.

\section{Submit your next manuscript to BioMed Central and take full advantage of:}

- Convenient online submission

- Thorough peer review

- No space constraints or color figure charges

- Immediate publication on acceptance

- Inclusion in PubMed, CAS, Scopus and Google Scholar

- Research which is freely available for redistribution

Submit your manuscript at www.biomedcentral.com/submit
Biomed Central 